to the meaning of the parable. Snodgrass (2008:252), for example, argues that the hyperbole underscores 'that the kingdom cannot be fitted into some previously existing system', for Hultgren (2000:421) it focuses on the way in which the merchant searches, whilst Hagner (2000:117) interprets the hyperbole as a reference to commitment. ${ }^{4}$

For some scholars, however, the action of the merchant is not hyperbolic and relevant to the meaning of the parable. According to Scott's (1990:319) interpretation, the total investment required to acquire the pearl relativises the value of the pearl. The merchant will have to sell the pearl, or else he will be broke. The value of the pearl only generates in being sold. 'The thing of value, the pearl, has no ultimate value'. This, Scott argues, indicates that the kingdom 'cannot be possessed as a value in itself'. The merchant will have to sell the pearl. 'And that is the kingdom's corrupting power the desire to possess it'.

For Miller (2007:65-82), the parable begins where it ends. The parable ends with the merchant left with owning nothing but the pearl; he has nothing left to make a living or support his family. What seems to be a happy ending is actually a no-win situation. As such, the parable typifies the merchant as a fool 'in the sense that the term "fool" has in the Jewish wisdom tradition' (Miller 2007:67). In this tradition the essence of wisdom is living with the long run in mind, with a fool being someone:

[W] hose short-sightedness and immature judgement makes him vulnerable to disasters that the wise know how to avoid. Fools are a danger to themselves and to others, not because they are malicious, but because they are foolish. (Miller 2007:69)

From this perspective, Miller (2007:76-81) argues, the parable is autobiographical. Jesus sees himself (and his followers) as the merchant. Like the merchant, Jesus was single-minded in his campaign on behalf of the kingdom, driven by his passion. He campaigned for the kingdom as if there was no tomorrow. This made him and his followers vulnerable; it made them foolish. This, however, is not the case when one is part of the kingdom. The kingdom blinds people by its beauty and goodness. It is because of that kingdom that they are willing to be foolish, and 'unwilling to envision a future for themselves in which they are not committed to it. They cannot respond otherwise' (Miller 2007:82). The parable, Miller thus argues, is counter-wisdom.

According to Levine (2014) commentators cannot conclude what the pearl represents because they perhaps are looking in the wrong place. The parable, she argues, challenges us to determine our own pearl of great price, our ultimate concern, which sometimes is just as absurd and unfulfilling as selling everything and in the end to be left with only a pearl. If we know what this is, we would be less acquisitive, and 'better able to love our neighbours, because we will know what is most important to them' (Levine 2014). As such, the parable

4.See also Montefiore (1909:644), Smith (1937:146), Oesterley (1936:84), Dodd (1961:86), Linnemann (1980:101), Stein (1981:103) and Gundry (1982:273) who interpret the act of the merchant as hyperbolic. tells us what we already know to be true, but do not want to acknowledge.

Levine is correct in her opinion that interpreters cannot conclude what the parable represents because they are looking at the wrong place. In all the interpretations of the parable, as the history of its interpretation shows, the focus is on the pearl. The focus of the parable, as will be argued below, read against the social realia (cultural scripts) evoked by this short narrative, should rather be the merchant and his actions. The pearl, as a metaphorical reference to the kingdom, should not be overemphasised in the interpretation of the parable. Read from this perspective, the parable is indeed about corruption, but not in the sense understood by Scott. As in the case of the Lost Sheep (see Van Eck 2011b:1-10), the parable is an unexpected story about outsiders. Using a merchant in a story about the kingdom of God would have shocked those who listened to the parable.

\section{Integrity and authenticity}

Two versions of the parable are documented, namely Matthew 13:45-46 and the Gospel of Thomas 76.1-3. ${ }^{5}$ Scholars in most cases see the Thomasine version as secondary because of its 'Gnostic' tendencies. Snodgrass (2008:250), for example, sees the pearl in the Thomasine version as referring to 'the inner self', Hultgren (2000:418) sees it as referring to 'the divine spark within the self', and Scott (1990:317) sees the pearl as 'a symbol for Christ or the soul', linking the Gospel of Thomas 76 to the hymn of the pearl in the Acts of Thomas 113:104-105 (see also Young 1998:203; Jones 1995:353).

Recently Patterson, Bethge and Robinson (2011) have argued convincingly that the Gospel of Thomas is not Gnostic. Patterson et al. (2011:33-38) date the Gospel of Thomas in the last decades of the 1st century, and place the sayings collection in the Gospel of Thomas within the well-used genre of ancient literature known as logoi sophon (sayings of the wise; Patterson et al. 2011:41). Rather than being Gnostic, the Gospel of Thomas is one of the earlier attempts to read the Jesus tradition through the lens of Middle Platonism (Patterson et al. 2011:47). The Gospel of Thomas' version of the parable therefore is not a 'Gnosticising' of the parable, but rather to accommodate his disapproval of mercantilism (Funk et al. 1993:515), as is the case in the Gospel of Thomas 64.2. This the Gospel of Thomas has done in several ways: The merchant is described as being prudent (Gos. Thom. 76.6). Because he is prudent, he does not sell all his belongings as in Matthew 13:46. The merchant in the Gospel of Thomas also does not find a pearl of great value ( $\pi 0 \lambda v ́ \tau \mu \mathrm{ov} \mu \alpha \rho \gamma \alpha \rho i ́ \tau \eta v ; ~ M t ~ 13: 46)$, but simply a pearl. ${ }^{6}$ Finally, the Gospel of Thomas adds Gospel

5.The Father's imperial rule is like a merchant who had a supply of merchandise and then found a pearl. The merchant was prudent; he sold the merchandise and bought the single pearl for himself. So also with you, seek his treasure that and bought the single pearl for himself. So also with you, seek his treasure that (Gos. Thom. 67.1-3; translation from Funk, Hoover \& The Jesus Seminar 1993:515).

6.Scott $(1990: 317$, n. 62$)$ notes that Matthew's description of the pearl found as . Scott (1990.317, n. 62) notes that Matthew's description of the pearl found as $\pi 0 \lambda v \tau \mu$ ov $\mu \alpha \rho \gamma \alpha \rho i \tau v$ (Mt 13:46) is peculiar since it fits a gnostic ideology at leas as well as and probably better than Thomas pearl. When read from the perspective that Thomas is not Gnostic, and in Thomas 76 is disapproving mercantilism, this difference between the two versions is not puzzling. 
of Thomas 76.3 to highlight his disapproval of mercantilism. Rather than looking for something that is failing (like a pearl), the hearers or readers of his sayings are called upon to look for something unfailing. ${ }^{7}$

The question whether the two extant versions stem from the same tradition, ${ }^{8}$ or from different traditions (see, e.g., Stein 1981:99), is difficult to answer. Whilst some scholars are of the opinion that the Thomasine version represents the original parable (e.g., Scott 1990:318; Hedrick 1994:129), others argue that the Thomasine version is derived from Matthew. ${ }^{9}$ Others, again, see the parable as stemming from Jesus, ${ }^{10}$ whilst some argue that the parable is a Matthean creation (e.g., Gundry 1982:275-277).

Although it is impossible to reconstruct the originating story Matthew and Thomas used for their respective versions with certainty, Hedrick (1994:127-129) and Breech (1983:74-76) make interesting and useful suggestions in this regard. According to Hedrick (1994:127), the structure of the parable in the two extant versions, excluding the redactional additions in both, is virtually identical. This identical structure, Hedrick argues, most probably consisted of the following sequence: The kingdom is like a merchant who found a pearl, who then went and sold and bought.

Breech's suggestion on the possible originating structure of the parable concurs with that of Hedrick. According to him, Matthew wanted to compare the kingdom with a treasure and a pearl, and redacted the versions of the two parables he received from the tradition to fit his purpose. Matthew, however, in the case of the Merchant, was not thorough enough in his editorial work. The original wording of the parable can be discerned behind his version in the expression 'the kingdom is like a merchant who ...' (Breech 1983:76). That the Treasure and the Merchant originally were worded in this way is confirmed by comparison with Thomas's versions, that respectively read 'the kingdom is like a man' and 'the kingdom is like a merchant' (Breech 1983:75). In short, Breech argues that the two parables initially were not about a treasure and a pearl, but about a man and a merchant; 'originally these parables were about specific men, not about

7. Contra Snodgrass (2008:250), who interprets Gospel of Thomas 76.3 as a Thomasine addition, linking its version of the Merchant to the parable of the Treasure. Snodgrass, like several other parable scholars, reads the parable of the Merchant in light of the Treasure (or vice versa), because Matthew transmitted them together. Since the Gospel of Thomas has transmitted these two parables separately - the Treasure is transmitted by the Gospel of Thomas as saying 109-these two parables Treasure is transmitted by the Gospel of Thomas as saying 109 - these two parables
should not necessarily be read in light of the other 'twin'. This study treats the two parables as independent from one another. See also Bultmann (1968:173) and Jeremias (1972:90-91), who are of the opinion that the two parables were transmitted to Matthew independent of one another.

8.See, for example, Scott (1990:318), Jeremias (1972:24), Breech (1983:75), Montefiore (1960:66-67) and Funk (et al. 1988:46), who argue that both versions stem from the same tradition and that both versions are a modification of an original version.

9.This is the point of view of Snodgrass (2008:250), Davies and Allison (1997:440), Luz (1990:275), Weder (1984:139) and Hultgren (2000:417-418).

10.Jeremias (1972:198), Bultmann (1968:173), Hultgren (2000:421), Jones (1995:352), Luz (1990:350), Dodd (1961:85-87) and Funk (et al. 1993:196) are of this opinion arguing to the Matthean version is the closest to the original. Scott (1990:318) and Hedrick (1994:117) are also of the opinion that the parable goes back to Jesus, but argue for the Thomas version to be the closest to the original parable. what they found, which is, in the view of the early Christian teacher, the kingdom' (Breech 1983:75; emphasis original).

Although Hedrick and Breech's reconstruction of the 'original' parable is hypothetical, it does make an important point. The parable in Matthew 13:45-46 initially was not a parable about a pearl, but a parable about a merchant; a story that challenged its hearers who, because of a feeling of superiority, 'regularize the everyday by imposing their normalizing patterns' on reality (Breech 1983:75). Versed differently, the parable depicts the kingdom as a new and different reality.

\section{A social-scientific and realistic reading of the parable of the merchant (Mt 13:45-46) Reading scenarios \\ Merchants}

Becausemostscholarsfocus on the pearl in theirinterpretations of the parable, it is not surprising that the merchant, the main character in the parable, has not received much attention. The little attention the merchant has received, are a few remarks regarding the kind of merchant that is being depicted in the parable and the merchant's social status. Jeremias (1972:199) describes the merchant as a 'wholesale trader, a big businessman' ("

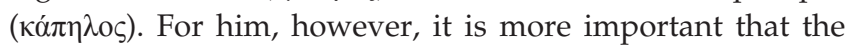
merchant is a dealer in pearls, which makes the merchant 'a secondary feature' in the parable. Hultgren (2000:419) makes the same distinction, quoting Plato's Republic 2.371D as evidence. ${ }^{11}$ With regard to the merchant's social status, Scott (1990:316) depicts the merchant as an upper-class character, and Miller (2007:66) describes the merchant as belonging to a class higher than the hearers of the parable.

The above description of the merchant identifies what can be termed as "that" or "what" information', but gives us 'less insight into the questions concerning "how", "why", and "what for"' (Elliott 1993:12). Elliott (1993) continues:

[I]n addition to details about specific individuals ... what might be known about how ancient societies were organized and operated? How were attitudes, expectations, values, and beliefs shaped by the ... social environment? How did shared social and cultural knowledge provide the basis for shared meaning and communication? (pp. 12-13; emphasis added)

What Elliott argues is that it is not enough to identify the merchant as a wholesale trader and someone belonging to a class higher than the hearers of the parable. More important to ask is what the hearer's beliefs (perceptions shaped by their cultural environment) were when it came to merchants, and how these beliefs influenced their attitude towards merchants. Put differently: What were the hearer's beliefs

11'Or is not shopkeepers (ov count in the agora, serve us in buying and selling, whilst we call those who roam from

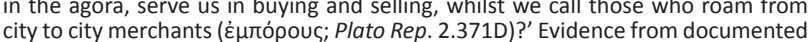
city to city merchants ( $\varepsilon \mu \pi$ ropouc; Plato Rep. 2.371D)?' Evidence from documented
papyri supports Plato's distinction between merchant and shopkeeper (see, e.g., papyri supports Plato's distinction between merchant and shopkeeper
P.Oxy. 136; P.Oxy. 10 1253; see also Philo, Opif. 147.6; Philo, los. 15.1). 
about and attitude towards merchants drawn from their common experience? And in what way did this common experience influence their reception of the parable? Using such experience as the source of the scenario in the parable, Malina and Rohrbaugh (2003:78) note that 'authors in highcontext societies ${ }^{12}$... presumed common knowledge between themselves and their audiences. Jesus seems able to depend on that since explanations are not provided'. Or, as phrased by Miller (2007):

The parables clearly require some context. For Jesus and the audience to which he pitched the parables, the context was their lived situation: what they brought to the telling and hearing of these oral stories. (p. 75)

What were the beliefs about merchants in the social context in which Jesus told the parable? And what was the common attitude towards someone who was a merchant (wholesale trader)? In other words, what was the shared social and cultural knowledge of the hearers of the parable that provided the basis for the shared meaning and communication that Jesus depended on when he told the parable?

Snodgrass (2008:251), when discussing the merchant as the one looking for pearls, in passing comments that some 'in the world had little respect for merchants', citing Sirach 26:29 as evidence. The only other reading of the parable that remarks on the perception that people may have had of merchants is that of Hultgren (2000), stating that although:

[S]ome Roman writers looked down upon them as a class, merchants were generally held in high regard among Jews. ${ }^{13}$ Yet even in Jewish tradition it could be said that a 'merchant ... can hardly keep from wrongdoing'. (p. 419; also citing Sirach 26:29)

Sirach (c. 190-170 BCE) in fact, makes several negative remarks about merchants. In Sirach 37:7-11, where he gives advice regarding those who cannot be trusted to give fair advice, he mentions merchants along with those who only counsel for their own benefit and are envious, cowards, buyers and sellers, the unmerciful and lazy, and idle persons. Also, in Sirach 41:17-42:5, in a list of things one should be ashamed of, he lists the indifferent selling by merchants (Sirach 42:5) along with whoring, unjust dealings, gazing at someone else's wife, upbraiding speeches before friends, and theft.

12.The importance of this aspect of the interpretation of ancient texts deserves the following lengthy quote from Malina and Rohrbaugh (2003:11): "The New Testament was written in what anthropologists call a "high-context" society. People who communicate with each other in high-context societies presume broadly shared, well-understood knowledge of the context of anything referred to in conversation or in writing ... Thus writers in such societies usually produce sketchy and impressionistic writings, leaving much to the reader's or hearer's imagination ... In this way, they require the reader to fill in large gaps in the unwritten portion of the writing. All readers are expected to know the context and therefore to understand the references in question. In this way, the Bible, like most documents written in the high-context Mediterranean world, presumes readers to have broad and adequate knowledge of its social context. It offers little by way of explanation.'

13.As evidence, Hultgren refers to Jeremias (1969:31, 49). The evidence cited by Jeremias are references to traders in $t$. Ter. X.9 and j. Peah I.6, 16c.53, where mention is made of a priest's shop. He also cites t. Betz. III. 8 and 205 that refers to two scholars who were merchants in Jerusalem all their life. Finally, Zech. 14.21 is two scholars who were merchants in Jerusalem all their life. Finally, Zech. 14.21 is cited as evidence for traders in the temple's sanctuary. Clearly, these references do
not refer to roaming wholesale traders, but to localised shopkeepers or localised places of trading or selling. It is most probably because of this 'positive' evidence places of trading or selling. It is most probably because of this 'positive' evidence
that Hultgren (2000:420) sees the merchant in the parable as a metaphorical that Hultgren $(2000: 420)$ sees
reference for the disciples.
Sirach's negative perception of merchants is especially echoed in the writings of Philo (25 BCE-50 CE). Philo, a Jewish Hellenistic writer and contemporary of Jesus, describes merchants and those who do business as impure and foolish, equating them with Balaam, the symbol of a vain people, a runaway and deserter (Philo Cher. X.32-33). The life of a merchant or commerce, Philo (Cher. X.34.4) continues, only leads to distress. In De migratione Abrahami 216-217, Philo describes the search for wisdom as the mind 'travelling through the land', but not in the absurd way merchants and dealers cross the seas for the sake of gain, without consideration for important things in life like 'the society of friends, or the unspeakable pleasures arising from wife, or children, or one's other relations, or love of one's country, or the enjoyment of political connections' (Philo Migr. 217). Merchants, in Philo's view, lack wisdom, the 'most beautiful and desirable of all possessions' (Migr. 218.1-2). They also lack reason devoted to contemplation (Philo Congr. 63), a vehement love for knowledge (Philo Congr. 64), and never take part in discussions on virtue (Philo Congr. 64); for instead of attending to these important matters, they turn their minds to mercantile affairs, the gains to be derived from their profession, and the enjoyments that derive from the indulgence of an amorous appetite (Philo Congr. 65). In a metaphoric reference to mercantilism, Philo advises that when setting out on a difficult journey (referring to Moses), what would be helpful are 'instruction, improvement, study, desire, admiration, enthusiasm, prophecy, and the love of doing good actions' (Philo Congr. 112), and not 'silver, nor any gold, nor any other of those things which consist of perishable materials' (Philo Congr. 112.1-2). Merchants also are barbaric slave-dealers (Philo Ios. 18-19) ${ }^{14}$ and at times ignorant confessed to gain (Philo Ios. 139). At the markets they are so wicked that they have to be put in subjection to the superintendents of the market who have to make sure that they do not practice any wicked manoeuvres to the injury of those who purchase from them (Philo Spec. 4.193194). Even when discussing the Essenes, Philo compares the Essenes's positive traits - keeping their own minds in a state of holiness and purity (Philo Prob. 75) and refraining from any kind of violence (Philo Prob. 78) - with mercantilism, one of the perverted occupations with wicked purposes (Philo Prob. 78).

Several other Greek, Roman and Jewish writings also depict merchants in a negative light. Herodotus of Halicarnassus (484-425 BCE), when discussing the classes in Egypt, places merchants below the swineherds (Hist. 2.164). The orations of Demosthenes (382-322 BCE) contain several negative references to merchants. From Contra Dionysodorum 1-4 it can be deduced that Dionysodorus, a merchant, took a loan from Demosthenes, but acted in a fraudulent manner and robbed the money he took as a loan. In In Theocrinem 1-12, Demosthenes argues in court that Theocrines has laid baseless charges against merchants, believing his charge would succeed because of the general perception that all merchants are dishonest. And in

14.See also Josephus (Ant. 12.209, 299), where a direct connection is made between mercantilism and slave trading, even young boys and girls. 
In Aristocratem 146-147 merchants, with farmers, silver miners and those who make speeches and move resolutions for hire, are named amongst the unprincipled breed of citizens. The Testament of the Twelve Patriarchs 4.6 describes merchants as sly and evasive. Cicero (106-43 BCE) lists wholesale merchants (with tax gatherers and usurers) as one of the vulgar trades, describing them as businessmen who make no profit 'without a great deal of downright lying; and verily, there is no action that is meaner than misrepresentation' (Cicero Off. 1.150.42). Herodianus (c. 170-240 CE), in his Ab excessu divi Marci. 4.10.4, depicts merchants as smugglers, and Diogenes Laertius (c. 300 $\mathrm{CE}$ ) laments the negative perception of commerce (traders), since the profession of medicine and farming, like trading, all are injurious to one man but beneficial to another (Lives Pyrrho IX.81). Diogenes most probably would not have made this remark if there was not a general negative perception of merchants.

Turning to biblical writings, James and Revelation also depict a negative image of merchants (and commerce). In James 4:13-16 merchants are described as being godless and evil. The only thing merchants ( $\dot{\varepsilon} \mu \pi$ o $\varepsilon v \sigma o ́ \mu \varepsilon \theta \alpha ;$ Ja 4:13) are

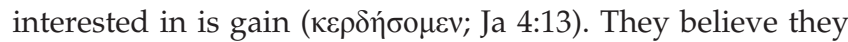
can plan their future without asking what the will of God is, and therefore their plans will vanish like mist. They boast in their arrogance, and 'all such boasting is evil' (Ja 4:15).

Revelation 18:3, 15 and 23 describe merchants as 'have grown

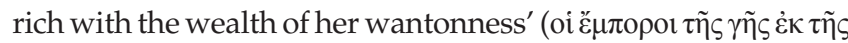

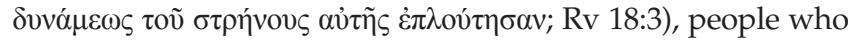

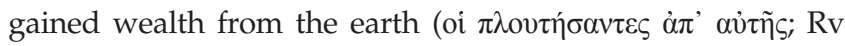
18:15), and as great men of the earth that deceived all nations

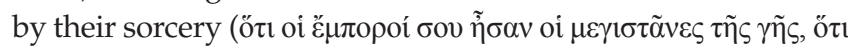

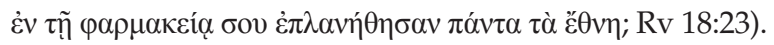

Finally, the Gospel of Thomas also paints a negative picture of merchants. In the Gospel of Thomas 64, the excuses in the parable of the Feast (buying a farm, buying five pair of oxen and having just got married; Q 14:18-20) are changed (and expanded) to recovering debt from merchants (Gos. Thom. 64.3), buying a house (Gos. Thom. 64.4), arranging a wedding banquet (Gos. Thom. 64.7) and buying an estate (Gos. Thom. 64.9). The parable in the Gospel of Thomas also ends with an added general remark that buyers and merchants would not enter the places of my father (Gos. Thom. 64.12; see Kloppenborg 2006:251). The Gospel of Thomas 76 also was edited to accommodate its disapproval of mercantilism by adding Gospel of Thomas 76.3 to highlight his disapproval of mercantilism.

The above evidence indicates a general trend of negative perception regarding merchants and mercantilism in the Mediterranean world, spanning an era from the 4th century BCE up to the 3rd century CE, and should therefore be taken into consideration in the interpretation of the Merchant.

\section{Limited good}

Why this negative perception of merchants and mercantilism (see Elliott 1993:12)? Persons who lived in the 1st century
(Mediterranean) world saw their existence as determined and limited by the natural and social resources of their immediate area and their world, a perception and belief that lead to the idea that all goods available to a person were limited; the so-called concept of limited good (Malina 1981:89; see also Malina 1987:354-367). ${ }^{15}$ The concept of limited good meant that a larger share for any individual or group resulted in a smaller share for someone else; in short, the pie was limited. Linked to the concept of limited good, as Rohrbaugh (1993:33) has indicated were the peasants' perception of production and the mode of exchange. Peasant production was primarily for use rather than exchange. Being subsistence economies, peasants saw the purpose of labour as maintaining the well-being of their family and the village; the purpose of labour was not to create wealth. Peasants thus evaluated the world of persons and things in terms of use, and not exchange. For peasants it was therefore acceptable to sell commodities in order to get money to buy other needed commodities; to use money to buy commodities which one then sold again at a profit was 'unnatural'. Profit-making was therefore seen as evil and socially destructive, since it would have been perceived as 'a threat to the community and community balance' (Malina 1981:97). Malina (1981) continues:

Since all goods are limited, one who seeks to accumulate capital is necessarily dishonourable ... A person could not accumulate wealth except through the loss and injury suffered by another. (p. 97)

Because of this perception, rich people were seen as evil and thieves. To gain more than one already had, was to steal from others. Traders (intercity import-export merchants), who were often freedmen or urban non-elite persons secretly subsidised by wealthy Roman citizens or other elites, ${ }^{16}$ fitted this category. Merchants 'bought needed commodities in one place and sold them in another at monopoly prices, getting as much as they could regardless of their own costs' (Malina 1981:98). All forms of capital accumulation, Malina (1981:98) emphasises, was perceived to be forms of usury (i.e., making money on the use of money), and:

$[P]$ rofit and gain normally refer to something that accrue to a person by fraud or extortion, that is, something other than wages, customary rent, reciprocal lending, or direct sale from producer to customer. (p. 98)

15.The concept of limited good was first developed by Foster (1965:296), who defined the concept as follows: ' $[B]$ road areas of peasant behavior are patterned in such the concept as follows: ' $[B]$ road areas of peasant behavior are patterned in such fashion as to suggest that peasants view their social, economic, and natura universes - their total environment - as one in which all of the desired things in ife such as land, wealth, health, friendship and love, manliness and honor, respect and status, power and influence, security and safety, exist infinite quantity and are always in short supply as far as the peasant is concerned. Not only do these and al other "good things" exist in finite and limited quantity, but in addition there is no way directly within peasant power to increase the available quantities' (emphasis added). See also Aristotle (Pol. 1.1256b): 'For the amount of such property sufficient in itself for a good life is not unlimited.'

16.Since the trafficking of wares (commerce) carried a stigma, Roman writers, many of whom were aristocrats, looked down on merchants and traders (D'Arms 1981:3-5). Keen to increase their wealth (with concomitant power and prestige), many aristocrats took part in commerce and trading. To avoid the stigma that was many aristocrats took part in commerce and trading. To avoid the stigma that was attached to merchants involved in trading and commerce, many of the aristocracy engaged in trade and commerce through 'agents' (trusted slaves or freedmen), acting as their patrons and in most cases supplying the capital (D'Arms 1981:391., see also Sidebotham 192.63). See also Demosthenes (Zenoth. 1-2, Lacr. 1-2; Pro Phorm. 1-4), from which the practice of patrons supplying capital (mostly in the form of loans) to merchants is clear. 
The trader, like the money lender and the tax collector, was therefore considered dishonourable, immoral, and basically godless (Malina 1981:98). The fact that merchants had to make use of ships for their import-export trade, and that most shipowners were non-Jewish (see Applebaum 1976:688), added to the negative perception the peasantry had of merchants.

Revelation, especially Revelation 18, gives expression to the general attitude towards merchants in the 1st century. In a social-scientific reading of Revelation, Oakman (2008:70-83) approaches the text of Revelation as a response to a specific socio-economic system (context). The context of the text, Oakman (2008:74) argues, is the political ancient economy of the 1st century Roman Empire. This economy was based on the forced extraction of goods (taxes), cash crops and commercial farming that constantly drained agricultural resources from the provinces to supply the elite and the city of Rome; an economy that encouraged trade and the movement of goods (commerce). Long distance trade needed merchants and shippers, which was organised by Rome by way of organised associations who did the bidding on their behalf (Oakman 2008:78; see n. 15). As a result of this political economy, a major transformation of the countryside took place; subsistence farming was replaced by a focus on commerce. This new approach did enormous harm to inland peasant farmers. Through taxes, rents and loans, the elite (and merchants $)^{17}$ appropriated more and more land, and the switch to commercial crops (livestock and wine) ${ }^{18}$ resulted in peasants becoming more dependent on the largesse of their patrons (Oakman 2008:80). Revelation, Oakman (2008:81) argues, 'speaks specifically against ... [this] ... political arrangements of Roman commerce' which God will overthrow and destroy, especially the merchants ( $\operatorname{Rv} 18: 11,15)$ and shipmasters (Rv 18:17): The merchants will weep and mourn, since no one will buy their cargo any more ( $R v 18: 11)$, and will stand far off, in fear of torment, weeping and mourning ( $R v$ 18:15).

\section{Reading the parable}

In the parable of the Merchant, the kingdom is likened to the actions of a merchant. As suggested earlier, the focus of the parable is firstly on the merchant, and not on what he found. The pearl only plays a secondary role in the meaning of the parable. For the first hearers of the parable, most probably peasants in Galilee, this depiction of the kingdom must have been shocking. Because of the perception of limited good in advanced agrarian societies, and the conviction that production was primarily for use rather than exchange (i.e., supporting immediate families and the village), the profits made by merchants were perceived as a form of usury and unnatural. Their trade was socially destructive and a threat

17.There is some evidence that merchants also owned large estates in 1st-century Palestine. Three Jewish merchants (Nakdimon ben Gorion, Kalba Sabbua and Ben Zizet Hakaset), according to Midrash Lamentations I, were able to provide Jerusalem with the necessary provisions for ten years (see Applebaum 1976:659). Applebaum (1976:659) remarks that this most probably means that they were not Applebaum (1976:659) remarks that this most probably means that they were not simply merchants, since 'they would have derived at least part of their produce from their own lands' (see also Applebaum 1976:687). Another merchant, Eleazer ben Harsum, owned several ships in the Hadrianic period, but his
large estates go back to the pre-70 period (Applebaum 1976:689).

18. Evidence from documented papyri supports this trend with several references to wine merchants (see, e.g., P.Oxy 7 1055; P.Oxy. 22 2342; P.Oxy. 31 2576). to the community. In the eyes of the peasantry, merchants were evil, and considered as being thieves. The fact that merchants had to make use of ships for their import-export trade, and that most shipowners were non-Jewish (see Applebaum 1976:688), added to this negative perception. Merchants owned large parts of land, and were part of the apparatus of the political ancient economy of the 1st century Roman Empire. They assisted the movement of goods accumulated through forced extraction of goods, cash crops and commercial farming. As such, merchants played a major role in the transformation of the peasantry's daily lives that focused on subsistence, and not commercial trade.

The peasantry's negative perception of mercantilism is echoed by several Jewish, Greek and Roman writers; mercantilism was generally seen as a perverted occupation with wicked purposes. Sirach links merchants with unjust dealings, and Philo depicts merchants as foolish only focusing on gain (see also Ja 4:13); they are slave traders and practice wicked manoeuvres to injure those who purchase from them. According to Demosthenes, merchants were part of the unprincipled breed of citizens, and in The Testament of the Twelve Patriarchs they are described as sly and evasive. Cicero lists them amongst the vulgar trades because of their dishonesty, and Herodianus depicts merchants as smugglers. In nuce, merchants personified the godless, symbolising everything that was unacceptable.

Thus the shock in the parable; the kingdom is like the actions of a merchant. Likening the kingdom to the unacceptable and the 'outsider', however was typical of Jesus' parables. In the parable of the Lost Sheep (Lk 15:4-6), the main character is a shepherd, someone also practicing a despised trade not to be followed. ${ }^{19}$ Shepherds were associated with tax collectors, not to be used as witnesses, perceived as robbers, and typified as dishonest people finding it difficult to repent and make restitution (see Van Eck 2011b:1-10). They were also associated with bandits and agitators (Kloppenborg \& Callon 2010:11), and, in a world dominated by honour and shame, considered as shameless persons: Being nomadic, shepherds were seen as thieves (grazing flocks on somebody else's property), and were rendered unclean because they belonged to one of the proscribed trades (i.e., ass drivers, tanners, sailors, butchers, and camel drivers). Jesus also depicted the kingdom itself as 'unclean', as can be seen from the parable of the Leaven (Q 13:20-21). Leaven, in the time of Jesus, was a symbol for moral evil, corruption, and the unclean (see Scott 2007:95-119). And in the parable of the Mustard Seed (Lk 13:14-18), the kingdom is likened to a man that plants a mustard seed in his garden, violating the law of diverse kinds (Scott 1990:381), and pollutes the garden. The garden is unclean, a symbol of chaos. As a metaphor for the kingdom, the kingdom of God is thus polluted and unclean (see Van Eck 2013a:226-254). In the parable of the Feast (Lk $14: 16 b-23)$ Jesus again uses the actions of an unacceptable

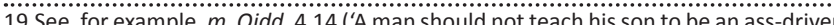
or a camel-driver, or barber or a sailor, or a herdsman or a shopkeeper, for their craft is the craft of robbers') and m. B. Qam. 10.9 ('None may buy wool or milk craft is the craft of robbers') and $m$. B. Qam. 10.9 ('None may buy wool or milk
from herdsmen, or wood or fruit from them that watch over fruit-trees') (Van Eck 2011c). 
figure to depict what the kingdom is like: A patron, part of the wealthy city elite (thus a 'thief'), competing for honour and being shunned by his peers, invites the unclean to his feast. By doing this, nullifies the role the pivotal value of honour played in organising a stratified society, as well as the purity system which deemed some socially and ritually (cultically) impure and unacceptable (see Van Eck 2103b:1-14). Finally, in the parable of the Samaritan (Lk 10:30-35), the actions of the figure of a despised and unclean Samaritan - probably also a merchant ${ }^{20}-$ is also used as a symbol for the kingdom.

Jesus therefore did not hesitate to use unacceptable or 'impure' figures as positive symbols for the kingdom. But how can the merchant in the parable be a positive symbol for the kingdom in what he does? On his travels, he finds a pearl. In the world of the hearers of the parable, pearls occupied 'the very highest position among all valuables' (Pliny the Elder Nat. 9.54), and thus were expensive. The merchant in the parable, however, does not find just another pearl; he

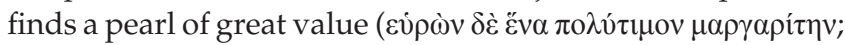
Mt 13:46). The value of the pearl is so high that he has to sell everything he owns to buy it. This act of the merchant is not hyperbolic, and indeed relevant to the meaning of the parable (contra, e.g., Linnemann 1980:101; Snodgrass 2008:252). His act of selling everything he owns, when not read hyperbolically, does not implicate that the parable should be seen as an autobiographical reference to Jesus (and his disciples; Miller 2007:76-81), or, as Scott (1990:319) argues, that the merchant now will have to sell the pearl, or else he will be broke. If this was implied by the parable, not only the merchant, but also Jesus would have been judged by the hearers of the parable as a fool. ${ }^{21}$

The merchant's selling of everything thus must refer to something else. This reading of the parable suggests that it means that the merchant has stopped being a merchant. He sold all he owned (most probably his merchandise; see Gos. Thom. 76.2), and took leave of the trade he practised. This is the focus of the parable, not the pearl. The role played by the pearl in the parable is secondary; only its value is of

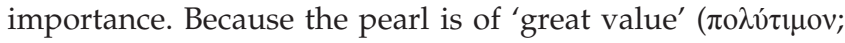
Mt 13:46), the merchant had to sell all his merchandise to acquire it. Being perceived by the hearers of the parable as the most valuable item that exists, Jesus could not have used a better example. Because he found a pearl, and in this case a very special pearl, he had to sell all he had.

Taking leave of the despised trade he practised, the merchant now is part of the kingdom. No more trading, including usury, will take place. In the kingdom there is no place for usury (see Van Eck 2011a:1-12), actions that are destructive and a threat to the community, or for being part of the apparatus of the exploitative political ancient economy of

20.The fact that the Samaritan, travelling for Jerusalem, had oil (ž $\lambda \alpha 10 v)$ and wine (oĩvov) with him (Lk 10:34), indicates that he most probably was a merchant.

21.In the Jewish wisdom tradition, the 'essence of wisdom is living with the long-run in mind ... The wise take the end into account and choose their path accordingly. Those without wisdom are fools, that is, those who are attracted by what is Those without wisdom are fools, that is, those who are attracted by what is
immediate and act without knowledge or regard for long-term consequences' (Miller 2007:67-68). the 1st century Roman Empire. Being part of the kingdom, one also cannot support the forced extraction of goods, cash crops and commercial farming to the detriment of those who already lived close to or below a level of subsistence.

In short: A merchant stopped being a merchant. An outsider has become an insider, and insiders act according to kingdom principles. Read from this perspective, Jesus, with this short parable, criticised the exploitative political economy of his day. Another option was available, typified by the actions of a despised merchant.

What will the once merchant do with the pearl? This question is left open to the hearers of the parable. Maybe he will sell the pearl and, like the shepherd in the Lost Sheep, do everything in his power to assist everybody in having enough (see Van Eck 2011b:1-10); invite, like the elite patron in the parable of the Feast, the 'polluted' and 'unclean' to his table (see Van Eck 2103b:1-14); or, like the Samaritan, come to the aid of those in need. This question, however, is not really important for the understanding of the parable. The parable already made its point; a despised outsider has become an insider for the benefit of those previously exploited by his actions.

Finally, the parable also challenged those who already became part of the kingdom. As Hultgren (2000:421) has argued, two implied themes in the parable are discipleship and commitment. If one wants to be part of the kingdom, one must be willing, like the merchant, to give up 'everything'. The parable, for example, also echoes Jesus' 'hard saying' in Luke 14:26:22 The kingdom is based on a new kind of (fictive) kinship. The one who is not willing to let go of the values that ruled the most important relationship of that time, namely kinship (e.g., patriarchy, status, honour), cannot be part of the kingdom.

\section{A parable of Jesus?}

The Merchant has all the markings of a Jesus parable. As indicated earlier, aspects of the parable resonate with the parable of the Lost Sheep (Lk 15:4-6), the Leaven (Q 13:2021), the Mustard Seed (Lk 13:14-18), the Feast (Lk 14:16b-23) and the Samaritan (Lk 10:30-35). Moreover, the condensed meaning of the parable, namely that the merchant stopped being a merchant, is consistent with the practice of Jesus in his ministry. When Jesus called tax collectors to follow him, they left their profession and followed him (e.g., Mk 2:13-14). As a disciple, the tax collector ceased to be a tax collector, and in the parable the merchant ceased to be a merchant as he disciples himself to the kingdom.

\section{Acknowledgements Competing interests}

The author declares that he has no financial or personal relationships which may have inappropriately influenced him in writing this article.

22. If any one comes to me and does not hate his own father and mother and wife and children and brothers and sisters, yes, and even his own life, he cannot be my disciple' (Lk 14:26; [RSV]). 


\section{References}

Applebaum, S., 1976, 'Economic life in Palestine', in S. Safrai \& M. Stern (eds.), The Jewish people in the first century. Historical geography, political history, social, cultural and religious life and institutions, vol. 2, pp. 631-700, Van Gorcum, Assen.

Armstrong, E.A, 1967, The gospel parables, Hodder \& Stoughton, New York.

Ball, M., 2000, The radical stories of Jesus: Interpreting the parables today, Regent's Park College, Oxford.

Blomberg, C.L., 2012, Interpreting the parables, 2nd edn., InterVarsity Press, Downers Grove.

Breech, J., 1983, The silence of Jesus: The authentic voice of the historical man Doubleday Canada Limited, Toronto.

Bultmann, R., 1968, History of the synoptic tradition, transl. J. Marsh, Blackwell, Oxford.

Buttrick, G.A., 1928, The parables of Jesus, Harper \& Row, New York.

Capon, R.F., 1985, The parables of the kingdom, William B. Eerdmans Publishing Company, Grand Rapids.

Cowan, D., 2007, Economic parables: The monetary teachings of Jesus Christ, Paternoster Publications, Colorado Springs.

D’Arms, J.H., 1981, Commerce and social standing in ancient Rome, Harvard University Press, Cambridge. http://dx.doi.org/10.4159/harvard.9780674331198

Davies, W.D. \& Allison, D.C., 1997, A critical and exegetical commentary on the gospel according to Saint Matthew, 3 vols., T\&T Clark, Edinburgh. (International Critical Commentary Series.)

Dodd, C.H., 1961, The parables of the kingdom, Charles Scribner's Sons, New York.

Donahue, J.R., 1988, The gospel in parable: Metaphor, narrative and theology in the Synoptic gospels, Fortress Press, Philadelphia.

Dwight, J., 1982, The parables of Jesus: Lessons in life from the master teacher, Kregel Publications, Grand Rapids.

Elliott, J.H., 1993, What is social-scientific criticism?, Fortress Press, Minneapolis. (Guides to Biblical Scholarship).

Fiensy, D., 2007, Jesus the Galilean: Soundings in a first century life, Gorgias Press, Piscataway.

Fisher, N.F., 1990, The parables of Jesus: Glimpses of God's reign, Crossroad, New York.

Foster, G.M., 1965, 'Peasant society and the image of limited good', American Anthropologist 67, 293-315. http://dx.doi.org/10.1525/aa.1965.67.2. 02a00010

Funk, R.W., Hoover, R.W. \& The Jesus seminar, 1993, The five gospels: The search for the authentic words of Jesus, Macmillan, New York.

Funk, R.W., Scott, B.B. \& Butts, J.R., 1988, The parables of Jesus: Red letter edition, Polebridge Press, Sonoma.

Glombitza, O., 1961, 'Der Perlenkaufmann: Eine exegetische Studie zur Matth. XIII.45-46', New Testament Studies 7(2), 153-161. http://dx.doi.org/10.1017/ S0028688500005361

Gundry, R., 1982, Matthew: A commentary on his literary and theological art, William B. Eerdmans Publishing Company, Grand Rapids.

Hagner, D.A, 2000, 'Matthew's parables of the kingdom (Matthew 13:1-52)', in R.N. Longenecker (ed.), The challenge of Jesus' parables, pp. 102-124, William B. Eerdmans, Grand Rapids.

Hedrick, C.W., 1994, Parables as poetic fictions: The creative voice of Jesus, Hendrickson Publishers, Peabody.

Hultgren, A.J., 2000, The parables of Jesus: A commentary, William B. Eerdmans, Grand Rapids.

Hunter, A.M., 1960, Interpreting the parables, Westminster Press, Philadelphia.

Jeremias, J., 1972, The parables of Jesus, SCM Press, London.

Jeremias, J., 1969, Jerusalem in the time of Jesus: An investigation into economic and social conditions during the New Testament period, transl. F.H. Cave \& C.H. Cave, SCM Press, London.

Jones, I.H., 1995, The Matthean parables: A literary and historical commentary, E.J. Brill, Leiden. (Supplements to Novum Testamentum, LXXX.)

Kloppenborg, J.S., 2006, The tenants in the vineyard: Ideology, economics, and agrarian conflict in Jewish Palestine, Mohr Siebeck, Tübingen. (Wissenschaftliche Untersuchungen zum Neuen Testament, 195).

Kloppenborg, J.S. \& Callon, C., 2010, 'The parable of the shepherd and the transformation of pastoral discourse', Early Christianity 1, 1-43.
Levine, A-J., 2014, ' 4 teachings from Jesus that everybody gets wrong', in Belief Blog, viewed 22 September 2014, from http://religion.blogs.cnn.com/2014/09/21/ four-teachings-from-jesus-that-everybody-gets-wrong/.

Linnemann, E., 1980, Parables of Jesus: Introduction and exposition, 5th edn., transl. J. Sturdy, SPCK, London.

Luz, U., 1990, Das Evangelium nach Matthäus, vol. 2, Mt 8-17, Benziger Verlag, Zurich. (Evangelisch-katholischer Kommentar zum Neuen Testament, l/2).

Malina, B.J., 1981, The New Testament world: Insights from cultural anthropology, Westminster John Knox Press, Louisville.

Malina, B.J., 1987, 'Wealth and poverty in the New Testament and its world', Interpretation 41(4), 354-367. http://dx.doi.org/10.1177/002096438704100403

Malina, B.J. \& Rohrbaugh, R.L., 2003, Social science commentary on the Synoptic gospels, 2nd edn., Fortress Press, Minneapolis.

Miller, R.J., 2007, 'The pearl, the treasure, the fool, and the cross', in E.F. Beutner (ed.), Listening to the parables of Jesus, pp. 65-82, Polebridge Press, Santa Rosa. (Jesus Seminar Guides, 2).

Montefiore, H.W., 1909, The Synoptic gospels, vol. II, Macmillan, London.

Montefiore, H.W., 1960, 'A comparison of the parables of the gospel according to Thomas and of the Synoptic gospels', in H.E.W. Turner \& H.W Montefiore (eds.), Thomas and the evangelists, pp. 40-78, Alec R. Allenson, Naperville. (Studies in Biblical Theology, 35.)

Oakman, D.E., 2008, Jesus and the peasants, Cascade Books, Eugene. (Matrix: The Bible in Mediterranean Context, 4.)

Oesterley, W.O.E., 1936, The gospel parables in the light of their Jewish background, SPCK, London.

Patterson, S.J., Bethge, H-G. \& Robinson, J.M., 2011, The fifth gospel: The gospel of Thomas comes of age, T\&T Clark, New York.

Rohrbaugh, R.L., 1993, 'A peasant reading of the talents/pounds: A text of terror', Biblical Theology Bulletin 23, 32-39. http://dx.doi.org/10.1177/014610799302300105

Scott, B.B., 2007, 'The reappearance of parables', in E.F. Beutner (ed.), Listening to the parables of Jesus, pp. 95-119, Polebridge Press, Santa Rosa. (Jesus Seminar Guides, 2.)

Scott, B.B., 1990, Hear then the parable: A commentary on the parables of Jesus, Fortress Press, Minneapolis.

Sidebotham, S.E., 1992, 'Trade and commerce (Roman)', in D.N. Freedman (ed.), The Anchor Bible Dictionary, Doubleday, New York, vol. 6, pp. 629-633.

Smith, B.T.D., 1937, The parables of the synoptic Gospels: A critical study, Cambridge University Press, Cambridge.

Snodgrass, K.R., 2008, Stories with intent: A comprehensive guide to the parables of Jesus, William B. Eerdmans, Grand Rapids.

Stein, R.H., 1981, An introduction to the parables of Jesus, The Westminster Press, Philadelphia.

Stern, D., 1991, Parables in Midrash: Narrative and exegesis in Rabbinic literature, Harvard University Press, Cambridge.

Stern, F., 2006, A rabbi looks at Jesus' parables, Rowman \& Littlefield, Oxford.

Trench, R.C., 1877, Notes on the parables of our Lord, Macmillan \& Co., London.

Van Eck, E., 2011a, 'Do not question my honour: A social-scientific reading of the parable of the minas (Lk 19:12b-24, 27)', HTS Teologiese Studies/Theological Studies 67(3), Art. \#977, 11 pages.

Van Eck, E., 2011b, 'In the kingdom everybody has enough - A social-scientific and realistic reading of the parable of the Lost Sheep (Lk 15:4-6)', HTS Teologiese Studies/Theological Studies 67(3), Art. \#1067, 10 pages.

Van Eck, E., 2011c, 'In the kingdom everybody has enough - A social-scientific and realistic reading of the parable of the lost sheep, (Lk 15:4-6)', HTS Teologiese Studies/Theological Studies 67(3), Art. \#1067, 10 pages.

Van Eck, E., 2013a, 'When kingdoms are kingdoms no more: A social-scientific reading of the Mustard Seed (Lk 13:18-19)', Acta Theologica 33(2), 226-254.

Van Eck, E., 2013b, 'When patrons are patrons: A social-scientific and realistic reading of the parable of the Feast (Lk 14:16b-23)', HTS Teologiese Studies/Theological Studies 69(1), Art. \#1375, 14 pages.

Wailes, S.L., 1987, Medieval allegories of Jesus' parables, University of California Press, Berkeley.

Weder, H., 1984, Die Gleichnisse Jesu als Metaphern: Traditions- und redaktionsgeschichtliche Analysen und Interpretationen, Vandenhoeck \& redaktionsgeschichtliche Analysen und Interpretationen, Ruprecht, Gottingen
Testaments 120.)

Young, B.H., 1998, The parables: Jewish tradition and Christian interpretation, Hendrickson, Peabody. 